\title{
Peran Program Kampung Sehat Dalam Peningkatan Ketahanan Pangan di Masa Pandemi Covid 19 (Studi Kasus Kelurahan Samapuin Kecamatan Sumbawa Kabupaten Sumbawa)
}

\author{
Awaluddin $^{1}$, Mega Trishuta Pathiassana ${ }^{2}$, I Putu Widiantara ${ }^{3}$, Harjito $^{4}$ \\ ${ }^{1}$ Sekolah Pascasarjana, Universitas Teknologi Sumbawa \\ Email : awaluddinkempo99.dtt@gmail.com \\ ${ }^{2}$ Fakultas Teknologi Pertanian, Universitas Teknologi Sumbawa \\ Email : mega.trishuta@uts.ac.id \\ ${ }^{3}$ Sekolah Pascasarjana, Universitas Teknologi Sumbawa \\ Email : iputuwidiantara@uts.ac.id \\ ${ }^{4}$ Fakultas Teknologi Pertanian, Universitas Teknologi Sumbawa \\ Email : harjito@uts.ac.id
}

\begin{abstract}
Covid-19 pandemic has given a negative impact in sector of food security. One of the program from government of Nusa Tenggara Barat, program lomba kampung sehat has successfully improved food security. We aim to explain the roles of Program Lomba Kampung Sehat in the improvement of food security in Kelurahan Samapuin, Kecamatan Sumbawa, Kabupaten Sumbawa. Here, the effect of Program Lomba Kampung Sehat to economy and social aspects are discussed as well. This work uses qualitative approach with structured interview to a number of informant which selected based on purposive sampling. Program Lomba Kampung Sehat successfully improved food security by empowering people while being supervised by Lurah, Bhabinkamtibmas, and Babinsa (Three Pilars). Economy and Social aspects are also affected by Program Lomba Kampung Sehat.
\end{abstract}

Keywords : Pandemic, Food Security, Kampung Sehat

Abstrak. Pandemi Covid-19 yang terjadi telah memberi dampak negatif di sektor ketahanan pangan. Salah satu program pemerintah Nusa Tenggara Barat yaitu Program Lomba Kampung Sehat mampu meningkatkan ketahanan pangan masyarakat. Penelitian ini bertujuan untuk membahas tentang peran Program Lomba Kampung Sehat dalam meningkatkan ketahanan pangan masyarakat di Kelurahan Samapuin, Kecamatan Sumbawa Kabupaten Sumbawa. Di sini, dampak Program Lomba Kampung Sehat pada aspek ekonomi dan sosial juga dibahas. Penelitian ini bersifat kualitatif dengan menggunakan wawancara secara terstruktur kepada informan yang ditentukan secara purposive sampling. Program Lomba Kampung Sehat mampu meningkatkan ketahanan pangan dengan cara memberdayakan masyarakat yang juga dibina oleh Lurah, Bhabinkamtibmas, dan Babinsa (Tiga Pilar). Program Lomba Kampung Sehat juga memberikan dampak positif terhadap aspek ekonomi dan sosial masyarakat Kelurahan Samapuin.

Kata Kunci : Pandemi, Ketahanan Pangan, Kampung Sehat

\section{PENDAHULUAN}

Bulan Maret 2020, Indonesia mendapat kasus pertama virus covid-19. Pemerintah mengeluarkan aturan untuk membatasi kegiatan di luar rumah dan berkerumun. Oleh karena hal ini, kegiatan perekonomian masyarakat seperti berdagang menjadi terhenti dan ini menyebabkan akses masyarakat terhadap kebutuhan pangan menjadi sangat sulit yang akhirnya berdampak kepada menurunnya ketahanan pangan masyarakat. Di Nusa Tenggara Barat di Kabupaten Sumbawa, telah 
diketahui mengalami penurunan dalam hal ketahanan pangannya (Masniadi, Angkasa, Karmeli, \& Esabella, 2020). Tidak hanya itu, oleh karena banyaknya aspek yang dipengaruhi oleh covid ini, ini dapat berpotensi untuk menimbulkan masalah sosial yang bersifat horizontal dan vertikal (Satya, 2020).

Dalam usahanya untuk memitigasi penyebaran virus ini, beberapa program dicanangkan oleh pemerintah. Salah satu program diluncurkan pada 19 Juni 2020 oleh pemerintah Nusa Tenggara Barat yang dinamakan program lomba kampung sehat. Meskipun pada dasarnya Program Lomba Kampung Sehat ini memiliki tujuan untuk meningkatkan kesadaran masyarakat akan pentingnya mematuhi protokol covid-19 dan menjaga keamanan keluarahan di kala pandemi, program ini secara tidak langsung memberikan dampak yang signifikan terhadap peningkatan ketahanan pangan masyarakat. Seperti yang terlihat di gambar 1, program ini merupakan program yang memberdayakan masyarakat dengan bantuan para pembina yang terdiri dari Lurah, Bhabinkamtibmas, dan Babinsa. Disini, Bhabinkamtibmas adalah Bhayangkara Pembina Keamanan dan Ketertiban Masyarakat (Bhabinkamtibmas) adalah anggota kepolisian Negara Republik Indonesia. Babinsa adalah Bintara Pembina Desa yang anggotanya adalah Tentara Nasional Indonesia.

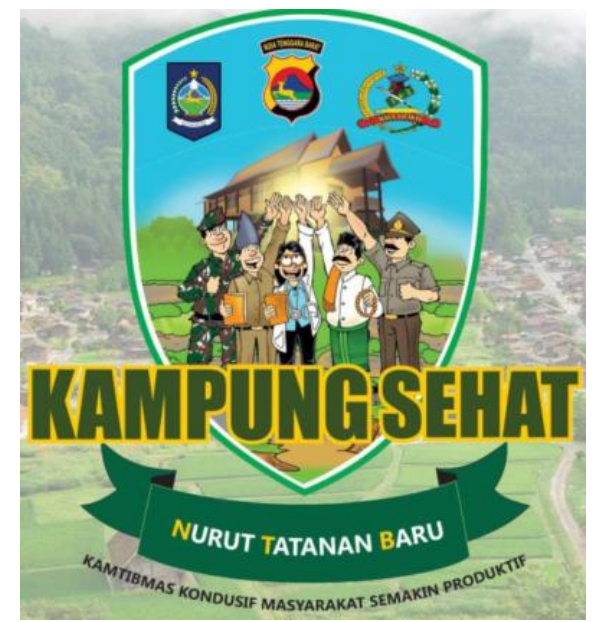

Gambar 1. Logo Program Lomba Kampung Sehat

Tujuan dari penelitian ini adalah untuk memaparkan tentang bagaimana program lomba kampung sehat ini dapat dengan baik meningkatkan ketahanan pangan masyarakat serta melihat dampaknya pada aspek ekonomi dan sosial. Penelitian ini diharapkan dapat menjadi rujukan untuk program pemerintah di masa mendatang yang bertujuan untuk meningkatkan ketahanan pangan di saat keadaan sulit seperti pandemi covid-19 ini.

\section{METODE PENELITIAN}

Penelitian yang digunakan disini bersifat kualitatif dengan pendekatan studi kasus di Kelurahan Samapuin, Kecamatan Sumbawa, Kabupaten Sumbawa. Wawancara dilakukan secara terstruktur kepada informan yang ditentukan secara purposive sampling dan pertanyaan wawancara sudah dipersiapkan sebelumnya. Pengumpulan data dilakukan dengan melakukan observasi, wawancara, dan pengumpulan data-data yang bersifat sekunder. Data yang diperoleh dianalisis menggunakan beragam sumber baik dari informan kunci maupun dari data sekunder. Analisis data dilakukan dengan reduksi data, penyajian data, dan penarikan kesimpulan (Sosiologi \& Makassar, 2021). 
Tabel Data Informan

\begin{tabular}{cccc}
\hline No & Nama & Status & Keterangan \\
\hline 1 & Dita Prisky, S.IP & Pejabat Pemerintahan & Lurah Samapuin \\
\hline 2 & Sudirman & Pejabat Pemerintahan & Sekretaris Lurah Samapuin \\
\hline 3 & Juliansyah Putra, SE & Pejabat Pemerintahan & Ketua RT \\
\hline 4 & Serda Syarifuddin Break & TNI & Babinsa \\
\hline 5 & Brigadir I Komang Arim Suyadi & Polri & Bhabinkamtibmas \\
\hline 6 & M. Iksan, S.Pd & Masyarakat & Budidaya Ikan Lele \\
\hline 7 & Joni Firmasnyah, S.Pd & Masyarakat & Budidaya jamur bongkol jagung \\
\hline 8 & Muhammad Nasyab, S.Pt & Masyarakat & Peternakan Ayam dan Perkebunan \\
\hline 9 & M. Mashud & Masyarakat & Perkebunan Sayur dan Buah \\
\hline 10 & Syafruddin & Masyarakat & Perkebunan Sayur dan Buah \\
\hline
\end{tabular}

\section{HASIL PENELITIAN DAN PEMBAHASAN}

A. Sinergi Antara Masyarakat Dengan Tiga Pilar Dalam Program Lomba Kampung Sehat.

Pada bagian ini akan dijelasakan komponen di dalam Program Lomba Kampung Sehat. Komponen pertama, adalah masyarakat di keluarahan Samapuin. Komponen kedua adalah pembina yang juga disebut tiga pilar yang di dalamnya terdiri dari Lurah, Bhabinkamtibmas, dan Babinsa. Masyarakat memiliki dua poin penting dalam peranannya di dalam kampung sehat ini. Pertama, masyarakat berperan sebagai objek sekaligus juga sebagai subjek dan memainkan peranan paling penting di dalam Program Lomba Kampung Sehat Hal ini sesuai dengan penelitian sebeulmnya yang mengatakan bahwa suatu program pemerintah dapat berhasil dijalankan dengan memanfaatkan potensi dari masyarakatnya untuk mencapai tujuan (Widiastuti, 2019). Masyarakat yang menjadi korban pandemi ini, memiliki potensi dalam dirinya karena ada motivasi untuk bertahan hidup memenuhi kebutuhan hidupnya dan juga keluarganya (Kurniawan, Khafid, \& Pujiati, 2016; Wahyudi \& Suryono, 2006). Mengenai hal tersebut, Lurah Samapuin, Dita Prisky, S.IP, mengatakan bahwa :

"Masyarakat merupakan ujung tombak dalam program ini karena setiap individu memiliki potensinya masing-masing apalagi jika diberikan dukungan. Di dalam program ini, kami mengharapkan masyarakat dapat meningkatkan ketahanan pangan keluarganya dan lebih baik lagi jika ternyata mampu membantu tetangga-tetangganya"

Sekretaris Lurah, Sudirman, juga mengungkapkan bahwa :

" Meskipun pada awalnya beberapa masyarakat menolak program ini, melalui bimbingan, masyarakat di Kelurahan Samapuin akhirnya dengan antusias mau menjalankan kegiatan ini oleh karena adanya motivasi dari dalam diri mereka sendiri"

Ketua RT, Juliansyah Putra, SE, menambahkan bahwa:

" Di dalam program ini setiap masyarakat memiliki potensi untuk menciptakan inovasi yang mana didorong oleh keinginan mereka untuk bertahan hidup di keadaan pandemi ini. Dapat dibayangkan jika banyak masyarakat yang mengikuti program ini, maka kita akan melihat banyak inovasi yang tercipta."

Hal ini selaras dengan teori bahwa di dalam keadaan yang sulit, manusia memiliki kecenderungan untuk berinovasi (Alfrian \& Pitaloka, 2020). Masyarakat disini dibagi menjadi beberapa kelompok yang terdiri dari POK Bidang Kesehatan, POK bidang sosial ekonomi (BSE), POK bidang keamanan, dan POK bidang info \& kreatifitas pada gambar 2. 


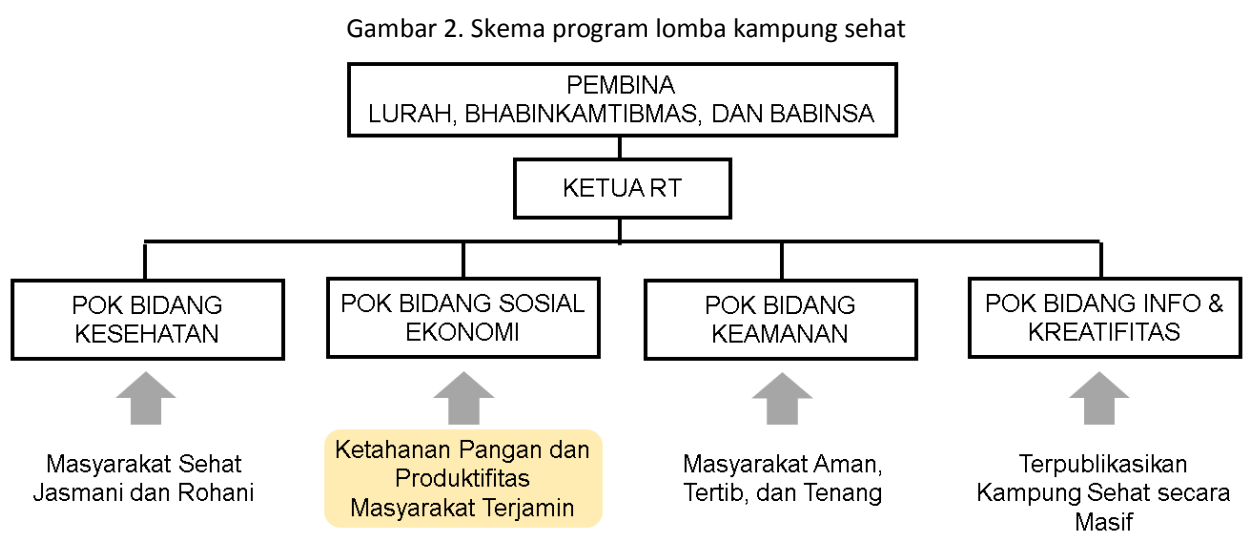

Masyarakat di dalam POK BSE inilah yang memiliki tujuan akhir untuk meningkatkan ketahanan pangan. Dalam pelaksanaan POK BSE ini masyarakat memulai usaha untuk menghasilkan produk pangan. Produk pangan yang menjadi pilihan usahanya tidak diatur oleh program ini atau dengan kata lain masyarakat diberikan kebebasan untuk menentukan produk pangan mana yang paling mereka pahami. Oleh karena masyarakat diberikan kebebasan untuk memilih ini maka masyarakat merasa yakin dengan kompetensinya dan ini berdampak kepada peningkatan kinerja dari masyarakat tersebut (Vernia \& Sandiar, 2020).

Kedua, masyarakat di NTB memiliki pekarangan di rumah mereka masing-masing yang bisa menjadi aset usaha yang dapat dimanfaatkan untuk menjalankan usaha produksi pangan. (Budiman, Arifin, Arifin, Astawan, \& Azra, 2014). Dari pekarangan yang ukurannya terbatas, masyarakat yang menjadi informan membuat usaha produk pangan diantaranya budidaya ikan lele, budidaya jamur bongkol jagung, peternakan ayam, dan perkebunan. Dari hasil wawancara yang dilakukan kepada informan, usaha yang dilakukan oleh masyarakat di kelurahan Samapuin telah mampu memenuhi kebutuhan pokok pangan masyarakat disitu.

Lurah memegang peranan untuk memberikan koordinasi kepada masyarakat di kelurahannya dan memberikan koordinasi kepada babinsa dan bhabinkamtibmas tentang keadaan serta informasi potensi usaha produk pangan di kelurahannya. Disni Lurah berperan sebagai pembina yang berperan untuk memberikan saran tentang usaha produk pangan yang dapat dilakukan masyarakat serta memberikan bantuan dalam hal informasi tentang cara melakukan usaha produk pangan tersebut. Tidak hanya itu, Lurah juga mencarikan bantuan-bantuan lain di luar kelurahannya untuk membantu perkembangan lomba kampung sehat di kelurahannya. Disini tugas Lurah sebagai pembina kampung sehat adalah menjadi pemberdaya masyarakat di lingkungannya (Saraswati, 2019). Dalam wawancara dengan masyarakat bernama Joni Firmasnyah, S.Pd yang memiliki budidaya jamur bongkol jagung, beliau mengungkapkan bahwa :

"Para pembina terutama pak Lurah banyak sekali memberikan ide, saran, dan masukan tentang bagaimana menjalankan usaha jamur bongkol jagung. Saya awalnya hanya suka saja untuk mengkonsumsinya dan tidak terpikir untuk menjadikannya usaha. Awalnya memang sulit, tapi seiring berjalannya waktu, menjalankan usaha ini menjadi mudah."

Hal serupa juga disampaikan oleh informan masyarakat lainnya. Informan, M. Iksan, S.Pd, selaku masyarakat yang membudidayakan lele mengatakan bahwa:

"Tidak terpikirkan sebelumnya akan melakukan budidaya lele. Ide untuk budidaya lele ini baru terpikirkan di masa pandemi ketika mengikuti program lomba kampung sehat ini. Saya dulu memang suka mengkonsumsi lele dan pak Lurah menyerahkan kepada saya tentang usaha apa yang ingin dijalankan. Kata beliau, nanti kalau sudah mulai menjalankan akan dibantu." 
Selain itu, informan bernama Muhammad Nasyab, S. Pt juga mengatakan bahwa :

"Ketika menjalankan program ini, saya banyak sekali menerima bantuan-bantuan dari berbagai pihak seperti Lurah, Bhabinkamtibmas, dan Babinsa. Bantuannya bisa berupa bantuan ide bahkan ada bantuan berupa pakan dari Lurah kita."

Bhabinkamtibmas dan Babinsa memiliki 2 tugas utama dalam hal ketahanan pangan ini. Yang pertama, Bhabinkamtibmas dan Babinsa bertugas untuk menjaga keamanan dari lingkungan tempat lomba kampung sehat ini diadakan. Salah satu informan yang berperan sebagai babinsa, Serda Syarifuddin Break menjelaskan bahwa :

"Kondisi pandemi covid-19 ini dapat berpotensi untuk menyebabkan adanya keributan atau tindak kriminal yang dilakukan oleh masyarakat. Hal ini didorong oleh karena tidak terpenuhinya kebutuhan sehari-hari dari masyarakat yang akhirnya menimbulkan munculnya pemikiran untuk melakukan tindakan yang tidak benar."

Keamanan dari lingkungan ini sangatlah penting oleh karena besarnya potensi untuk terjadinya konflik sosial di kala pandemi ini (Satya, 2020). Dengan terjaminnya keamanan di lingkungan Kelurahan Samapuin tersebut, masyarakat menjadi tenang dan dapat mengerjakan pekerjaannya dengan lebih tenang tanpa stress (Mawanza, 2017). Yang kedua, bhabinkamtibmas dan Babinsa memberikan bantuan dalam hal membeli kebutuhan yang diperlukan masyarakat misalnya polybag untuk menanam ataupun bantuan berupa bibit. Bhabinkamtibmas, Brigadir I Komang Arim Suryadi mengatakan bahwa :

"Jajaran Bhabinkamtibmas akan selalu memberikan dukungan kepada masyarakat yang ingin berkreasi dengan usahanya dan kami selaku anggota Bhabinkamtibmas akan berusaha membantu sekuat tenaga. Selain itu kita juga senantiasa memberikan bantuan yang diminta oleh masyarakat seperti polybag, pupuk, dll. Kita juga senang melihat ada pencapaian yang didapat oleh masyarakat."

Dari observasi yang dilakukan peneliti, dapat ditemukan bahwa terjadi sinergi yang sangat baik antara masyarakat dengan tiga pilar. Hal ini terlihat dari intennya kunjungan komponen tiga pilar terutama bhabinkamtibmas dan babinsa ke rumah masyarakat untuk membantu dalam hal POK bidang sosial ekonomi yang memiliki tujuan untuk meningkatkan ketahanan pangan. Hal ini terjadi karena usaha masyarakat untuk berusaha dalam hal produk pangan ini dirasa penting untuk dibantu karena ketahanan pangan merupakan hal penting yang sifatnya krusial (Conceição, Levine, Lipton, \& Warren-Rodríguez, 2016).

\section{B. Tiga Indikator Untuk Membuktikan Peningkatan Ketahanan Pangan Dalam Lomba Kampung Sehat}

Untuk menganalisis tercapainya peningkatan ketahanan pangan maka tiga indikator ketahanan pangan yang diambil dari Global Food Security Index (GFSI) yang disusun oleh The Economist Intelligence Unit dan telah dipergunakan di 113 negara ("Global Food Security Index," 2020; The Economist Intelligence Unit, 2017). Di dalam GFSI, ketahanan pangan terdiri dari beberapa indikator yang mana tiga diantaranya sangat esensial. tiga indikator tersebut adalah Affordability, Availability, dan Food quality and safety.

Affordability, adalah indikator ketahanan pangan pertama yang mana menjelaskan tentang kapasitas masyarakat untuk dengan mudah mendapatkan produk pangannya.

Ketika pandemi, masyarakat dihadapkan dengan kondisi yang harus berada di rumah, kebanyakan masyarakat yang bermata pencaharian sebagai pedagang tidak mampu lagi untuk mendapatkan 
penghasilan. Kurangnya penghasilan ini menurunkan daya beli masyarakat terhadap produk pangan. Dalam hal ini berarti indikator ketahanan pangan pertama, affordability, dapat dikatakan tidak tercapai.

Ketika program lomba kampung sehat dijalankan. Masyarakat di kelurahan yang berpartisipasi memiliki usaha produksi pangan dan mereka mampu memenuhi kebutuhan produk pangan sehariharinya untuk keluarganya. Namun, produk pangan yang mereka hasilkan ternyata bisa untuk memenuhi kebutuhan pangan tetangganya yang lain. Di sini, masyarakat yang memiliki produk pangan menjual produknya dengan harga yang murah bahkan ada yang dengan sukarela membagikan produk pangannya dengan dasar membantu. Tidak ada monopoli produk dan masyarakat tidak menentukan harganya dengan sembarangan. Hasil wawancara dengan salah satu informan masyarakat, Syarifuddin, yang memeiliki usaha perkebunan mengatakan bahwa :

"Saya memberikan harga sangat murah bahkan kalau misalnya ada warga yang tidak mampu untuk membayar, maka saya akan memberikannya dengan cuma-Cuma. Saya lakukan ini atas dasar sukarela karena saya tahu kita sedang dalam kondisi yang buruk sehingga disini kita harus saling membantu".

Hal ini karena di Indonesia, telah tertanam jiwa gotong royong yang mana masyarakat membantu dengan sukarela tetangganya ketika terjadi permasalahan (Rochmadi, 2012). Availability, adalah indikator kedua yang menyatakan kapasitas masyarakat untuk mensuplai produk pangan dan meyakinkan kemudahan akses oleh masyarakat. Ketika pandemi terjadi, pasar yang menjadi tempat utama untuk mendapatkan sumber pangan harus ditutup karena adanya himbauan untuk social distancing. Oleh karena itu, masyarakat mengalami kesulitan untuk mengakses sumber pangan. Dalam hal ini, indikator kedua tidak tercapai ketika pandemi covid-19. Dalam hal ketersediaan produk pangan, pemerintah telah berusaha melakukan beberapa jenis mitigasi terhadap krisis ketersediaan pangan ini dengan memperbaiki manajemen petaninya (Jusriadi, Mm, Kamaluddin, \& Aljurida, 2020). Dalam program lomba kampung sehat ini, masyarakatnya sendiri yang diberdayakan untuk membantu pemerintah untuk menghasilkan produk pangan dan menjamin ketersediaannya di wilayahnya masing-masing. Informan masyarakat yang memiliki usaha produksi pangan mengatakan bahwa mereka tidak memilih siapa saja tetangga yang bisa mendapatkan produk pangan mereka. Mereka tidak mengincar keuntungan dengan menjual kepada siapa yang bisa membayar lebih mahal karena mereka sadar bahwa mereka bersama-sama sedang di dalam keadaan sulit dalam pandemi ini (Martianto, Alfiasari, \& Hadi Dharmawan, 2009; Saheb, Slamet, \& Zuber, 2013; Utami \& Suprapti, 2020).

Food quality \& safety mengukur kualitas dan nutrisi yang terkandung di dalam bahan pangan. Ketika program lomba kampung sehat diadakan, kualitas produk pangan yang dihasilkan terjamin keamanannya oleh karena sedikit penggunaan pestisida yang diakibatkan karena tidak terlalu luasnya pekarangan yang dipergunakan untuk perkebunan (Destianto \& Pigawati, 2014).. Informan masyarakat, Syafruddin dan M. Mashud, menyatakan bahwa:

\section{"Pekarangan yang terbatas tidak mengharuskan mereka untuk menggunakan terlalu banyak pesitsida."}

Selain itu, informan masyarakat, Joni Firmansyah, S.Pd, yang memiliki usaha budidaya jamur bongkol jagung menggunakan pupuk untuk perkebunannya dari limbah bongkol jagungnya sehingga dapat mengurangi penggunaan pupuk UREA. Ide ini dapat terwujud karena adanya perasaan aman dan nyaman ketika menggeluti pekerjaannya serta mendapatkan masukan dari lurah melalui media internet. 


\section{Dampak Kampung Sehat Terhadap Aspek Ekonomi dan Sosial Masyarakat Kelurahan Samapuin.}

Dengan meningkatnya ketahanan pangan masyarakat, program lomba kampung sehat ini telah memberikan dampak kepada aspek ekonomi dan sosial. Untuk aspek ekonomi, masyarakat yang memiliki usaha produk pangan mendapatkan tambahan pendapatan yang diperoleh dari hasil penjualan produk pangan kepada tetangganya. Berdasarkan hasil wawancara dengan Joni Firmansyah, S.Pd., didapatkan bahwa :

"Jumlah total produk pangan yang dipanen, setelah dikurangi dengan jumlah produk pangan untuk dikonsumsi keluarga saya, produk pangan yang dihasilkannya dijual kepada masyarakat baik di dalam maupun di luar kelurahan tersebut. Hasil penjualan ini, jika dikurangi dengan biaya untuk melanjutkan usaha produk pangan maka besarnya biaya adalah sekitar 60\% dari hasil penjualan. Dari sini maka terdapat sisa $40 \%$ sisa dari penjualan dan ini dapat ditabung."

Penghasilan ini berasal dari kreativitas masyarakat untuk memasarkan produknya. Untuk kasus informan pengusaha jamur bongkol jagung menggunakan media online seperti facebook untuk memasarkan produknya. Informan masyarakat lainnya punya metodenya sendiri untuk dapat memastikan produknya dapat terjual dengan baik kepada tetangga maupun masyarakat di luar kelurahan tersebut. Ide-ide ini muncul karena ada keinginan untuk memastikan usaha yang dilakukan dapat berlanjut terus untuk memenuhi kebutuhan hidup dirinya dan keluarganya di situasi sulit (Hardilawati, 2020).

Untuk aspek sosial, program lomba kampung sehat ini secara tidak langsung telah memperkuat hubungan antara masyarakat dengan komponen tiga pilar dan antar komponen di dalam tiga pilar itu sendiri. Hal ini terlihat dari akrabnya masyarakat dengan komponen tiga pilar. Menurut wawancara seorang informan masyarakat, dirinya mengatakan tidak akan dapat berhasil untuk menjalankan usaha produksi pangan ini jika tidak dibantu oleh Lurah yang selalu memberikan masukan tentang usaha yang dapat dijalankan dan juga bantuan dalam bentuk informasi dan barang yang diberikan selama proses menjalankan usaha tersebut. Kemudian juga Bhabinkamtimbas dan Babinsa yang selalu hadir untuk mengingatkan kepada masyarakat tentang protokol kesehatan sambil datang membawakan bahan bantuan dalam bentuk jasa atau barang hampir setiap hari. Ini secara tidak langsung membangun hubungan sosial yang baik antara masyarakat dengan tiga pilar. Kemudian juga, dari penjabaran di atas tentang bagaimana masyarakat dengan sukarela menjual produk pangannya dengan harga yang sesuai dengan kondisi pandemi ini menghasilkan hubungan yang baik antara masyarakat dengan masyarakat lainnya. Hal ini merupakan ciri khas masyarakat yang secara alami muncul ketika berada dalam kondisi yang mana memerlukan orang-orang untuk bersatu bergotong royong untuk dapat keluar dari kondisi sulit (Rochmadi, 2012).

\section{KESIMPULAN}

Ketahanan pangan di masa Pandemi covid-19 mengalami penurunan drastis termasuk masyarakatnya di Nusa Tenggara Barat. Program lomba kampung sehat yang dicanangkan pemerintah NTB mampu memulihkan ketahanan pangan masyarakat dengan sangat baik. Keberhasilan program lomba kampung sehat dalam meningkatkan ketahanan pangan masyarakat disebabkan oleh adanya sinergi antara masyarakat yang menjadi objek sekaligus subjek dalam program tersebut dengan tiga pilar yang terdiri dari Lurah, Bhabinkamtibmas, dan Babinsa. Hal ini terbukti dari tercapainya tiga indikator ketahanan pangan yang terdiri dari affordability, availability, dan food quality \& safety. Oleh karena tercapainya ketahanan pangan ini, terjadi peningkatan juga dalam aspek ekonomi dan sosial yang dirasa sangat terpengaruh oleh adanya pandemi ini. 


\section{DAFTAR PUSTAKA}

Alfrian, G. R., \& Pitaloka, E. (2020). Strategi Usaha Mikro, KEcil, dan Menengah (UMKM) Bertahan pada Kondisi Pandemik Covid 19 di Indonesia. Seminar Nasional Terapan Riset Inovatif (SENTRINOV) Ke-6, 6(2), 139-146.

Conceição, P., Levine, S., Lipton, M., \& Warren-Rodríguez, A. (2016). Toward a food secure future: Ensuring food security for sustainable human development in Sub-Saharan Africa. Food Policy, $60,1-9$.

Destianto, R., \& Pigawati, B. (2014). Analisis Keterkaitan Perubahan Lahan Pertanian Terhadap Ketahanan Pangan Kabupaten Magelang Berbasis Model Spatio Temporal Sig. Geoplanning: Journal of Geomatics and Planning, 1(1), 21-32.

Global Food Security Index. (2020). . Retrieved November 21, 2020, from https://foodsecurityindex.eiu.com/Country/Details\#Indonesia

Hardilawati, W. laura. (2020). Strategi Bertahan UMKM di Tengah Pandemi Covid-19. Jurnal Akuntansi dan Ekonomika, 10(1), 89-98.

Jusriadi, A., Mm, S. T., Kamaluddin, L. A., \& Aljurida, A. M. A. (2020). MANAJEMEN MITIGASI KRISIS PANGAN DI ERA PANDEMI COVID-19 FOOD, (November), 216-227.

Kurniawan, A., Khafid, M., \& Pujiati, A. (2016). Pengaruh Lingkungan Keluarga, Motivasi, dan Kepribadian Terhadap Minat Wirausaha Melalui Self Efficacy. Journal of Economic Education, 5(1), 100-109. Retrieved from https://bit.ly/36BxWvm

Martianto, D., Alfiasari, ., \& Hadi Dharmawan, A. (2009). Modal Sosial Dan Ketahanan Pangan Rumah Tangga Miskin Di Kecamatan Tanah Sareal Dan Kecamatan Bogor Timur, Kota Bogor). Sodality: Jurnal Sosiologi Pedesaan, 3(1), 125-152.

Masniadi, R., Angkasa, M. A. Z., Karmeli, E., \& Esabella, S. (2020). Telaah kritis ketahanan pangan Kabupaten Sumbawa dalam menghadapi pandemi covid-19. Sosial Sciences and Humanities, 1(2), 109-120. Retrieved from https://www.semanticscholar.org/paper/Telaah-KritisKetahanan-Pangan-Kabupaten-Sumbawa-MasniadiAngkasa/96a263bec0421c692e06e595fae17a9f1bd345d7

Mawanza, W. (2017). The Effects of Stress on Employee Productivity: A Perspective of Zimbabwe's Socio-Economic Dynamics of 2016. Journal of Economics and Behavioral Studies, 9(2), 22-32.

Rochmadi, N. (2012). Menjadikan Nilai Budaya Gotong-Royong Sebagai Common Identity. Reporsitory Perpustakaan Universitas Negeri Malang.

Saheb, Slamet, Y., \& Zuber, A. (2013). Peranan Modal Sosial bagi Petani Miskin untuk Mempertahankan Kelangsungan Hidup Rumah Tangga di Pedesaan Ngawi (Studi Kasus di Desa Randusongo Kecamatan Gerih Kabupaten Ngawi Provinsi Jawa Timur). Jurnal Analisa Sosiologi, 2(1), 17-34.

Saraswati, E. E. (2019). Pengorganisasian Masyarakat dalam Meningkatkan Ketahanan Pangan melalui Pertanian Holitkultura Ramah Lingkungan di Dusun Balongkore Desa Ngadirejo Kecamatan Wonoasri Kabupaten Madiun.

Satya, P. A. N. I. P. (2020). Covid- 19 Dan Potensi Konflik Sosial. Jurnal Ilmiah Hubungan Internasional, $O(0)$.

Sosiologi, P. P., \& Makassar, U. M. (2021). Sosiologi, IX(April), 1-8.

The Economist Intelligence Unit. (2017). Global Food Security Index 2017: Measuring Food Security and the Impact of Resource Risks. The Economist Intelligence Unit, 1-56. Retrieved from http://foodsecurityindex.eiu.com/

Utami, Q., \& Suprapti, I. (2020). FAKTOR MODAL SOSIAL TERHADAP KETAHANAN PANGAN RUMAH TANGGA PETANI JAGUNG LOKAL DESA GULUK GULUK KABUPATEN SUMENEP, 1, 138-150.

Wahyudi, A., \& Suryono, J. (2006). Analisis Pengaruh Gaya Kepemimpinan, Motivasi dan Lingkungan Kerja Terhadap Kinerja Pegawai. Jurnal Manajemen Sumber Daya Manusia, 1(1), 1-14.

Widiastuti, R. N. (2019). Inovasi Kampung Tematik. Journal of Politic and Government Studies, 8(3), 351-360. 